bahasa \& sastra, Vol. 14, No.1, April 2014

\title{
PENILAIAN PORTOFOLIO BERBASIS GAYA BELAJAR SISWA DALAM MATA PELAJARAN BAHASA INDONESIA SEBAGAI IMPLEMENTASI PENILAIAN KURIKULUM 2013
}

\author{
Wikanengsih \\ STKIP Siliwangi Bandung \\ Korespondensi: Jln. Terusan Jenderal Sudirman, Cimahi, Bandung \\ Pos-el: wikanengs@yahoo.com
}

\begin{abstract}
Abstrak
Kurikulum 2013 telah diberlakukan pemerintah pada setiap jenjang sekolah meskipun secara bertahap. Pelaksanaan tersebut menantang praktisi pendidikan khususnya guru dalam menguasai berbagai perangkat pendukung pembelajaran. Tulisan ini bertujuan untuk mengkaji dan menelaah perangkat pembelajaran yang diperlukan oleh Kurikulum 2013 khususnya perangkat untuk penilaian. Penilaian seperti diamanahkan Kurikulum 2013 berupa penilaian berbasis kompetensi yang harus mengukur kompetensi sikap, keterampilan, dan pengetahuan dengan berdasarkan pada proses dan hasil belajar. Adanya penilaian terhadap proses dan hasil belajar, instrumen penilaian portofolio merupakan instrumen utama dalam penilaian. Penilaian portofolio yang biasa digunakan guru dewasa ini belum memperhatikan masalah karakteristik siswa secara optimal sehingga perlu dikaji tentang penilaian portofolio yang memerhatikan karakteristik siswa dari segi gaya belajarnya. Berdasarkan hasil kajian terhadap beberapa literatur maka ditemukan sistem penilaian dengan menggunakan portofolio berbasis gaya belajar siswa yang meliputi gaya visual, auditori dan kinestetik.
\end{abstract}

Kata-Kata Kunci: portofolio, gaya belajar, kurikulum 2013

\begin{abstract}
Curriculum 2013 has been implemented by the government at every level of school though gradually. This implementation requires educational practitioners particularly teachers to master a variety of learning support tools. This paper aims to examine and review the learning tools needed by a particular device for Curriculum 2013 assessment. Assessment as mandated by Curriculum 2013 is a competency-based assessment to measure attitudes, skills, and knowledge based on the process and learning outcomes. Incorporating an assessment of the process and learning outcomes, portfolio is the main instrument in the assessment. The portfolio that is commonly used nowadays has not addressed students' characteristics and their learning styles. Review of the literature students' learning styles-based protofolio including visual, auditory and kinesthetic styles.
\end{abstract}

Key Words : portfolio, learning styles, curriculum 2013

\section{PENDAHULUAN}

Perubahan standar penilaian yang dicanangkan pemerintah dalam Kurikulum 2013 memerlukan perhatian guru secara optimal karena proses penilaian merupakan hal penting dalam sebuah pembelajaran. Sebagaimana tercantum dalam Kurikulum 2013 bahwa salah satu perubahan yang diakui pemerintah dalam Kurikulum 2013 adalah standar penilaian, dari penilaian hasil menjadi penilaian proses. Terlepas dari benar tidaknya bahwa standar penilaian dari hasil ke proses itu merupakan sebuah terobosan baru dalam kurikulum 2013-karena sebenarnya KTSP pun sudah menghendaki penilaian dilakukan terhadap proses belajar dan hasil belajar-, namun sebagai pelaksana di lapangan, guru 
harus memberi perhatian serius terhadap amanah kurikulum baru tersebut.

Bentuk keseriusan guru dalam mengimplementasikan isi kurikulum dalam hal standar penilaian yaitu melalui kegiatan mengkaji dan mempelajari bentuk-bentuk penilaian yang cocok dengan amanah kurikulum itu. Bentuk penilaian yang dikehendaki adalah penilaian otentik. Mengapa penilaian otentik? Hal ini berkaitan dengan penetapan pendekatan pembelajaran scientific yang diberlakukan berkaitan dengan penetapan standar kompetensi lulusan yang memiliki tujuan untuk meningkatkan dan menyeimbangkan antara soft skills dan hard skills yang meliputi aspek kompetensi sikap, keterampilan, dan pengetahuan. Hal itu merujuk pada Peraturan Presiden no 8 tahun 2012 tentang Kerangka Kualifikasi Nasional Indonesia (KKNI). Dalam peraturan tersebut pasal 1 poin 2 mengemukakan bahwa capaian pembelajaran adalah kemampuan yang diperoleh melalui internalisasi pengetahuan, sikap, keterampilan, kompetensi, dan akumulasi pengalaman kerja. Oleh karena itu, untuk mencapai kompetensi lulusan yang sesuai dengan konsep KKNI maka proses pembelajaran harus selaras dengan hal tersebut. Pencapaian kompetensi pengetahuan, peserta didik dituntut untuk mengetahui apa; pencapaian kompetensi sikap, siswa dituntut tahu mengapa; pencapaian kompetensi keterampilan, siswa dituntut tahu bagaimana. Pencapaian akhir dari sebuah proses pembelajaran adalah peningkatan dan keseimbangan antara kemampuan untuk menjadi manusia yang baik (soft skills) dan manusia yang memiliki kecakapan dan pengetahuan untuk hidup secara layak (hard skills) dari peserta didik. Oleh karena itu, penilaian otentik sangatlah tepat untuk digunakan.

\section{PENILAIAN PORTOFOLIO}

Penilaian portofolio merupakan salah satu bentuk penilaian otentik dalam pembelajaran. Yang dimaksud penilaian otentik itu sendiri adalah penilaian sebenarnya yang dilakukan guru terhadap siswa pada saat proses belajar berlangsung serta hasil belajarnya. Rustaman mengemukakan bahwa tipe tugas penilaian otentik dapat diwujudkan dalam berbagai bentuk, yaitu: 1) computer adapting testing; 2) tes pilihan ganda diperluas; 3) extended respon atau open ended question; 4) group performance assesment; 5) interviu; 6) observasi partisipasif; ; 7) portofolio; 8) mengkonstruksi jawaban. Berdasarkan tipetipe penilaian otentik sebagaimana dikemukakan di atas, portofolio termasuk di dalamnya.

Arifin (2011:4) mengemukakan bahwa penilaian portofolio merupakan pendekatan yang bertujuan mengukur sejauhmana kemampuan peserta didik dalam mengkonstruksi dan merefleksi suatu tugas/karya melalui pengumpulan yang relevan dengan tujuan pembelajaran sehingga hasil konstruksi dapat dinilai oleh guru dalam periode tertentu. Sebagai instrumen penilaian, portofolio difokuskan pada dokumen tentang kerja siswa yang produktif, yaitu bukti tentang apa yang dapat dilakukan oleh siswa, bukan apa yang tidak dapat dikerjakan (dijawab atau dipecahkan) oleh siswa. (Depdiknas, 2004: 3). Yamin ( 2011: 278) mengemukakan bahwa portofolio adalah suatu kumpulan pekerjaan peserta didik dengan maksud tertentu dan terpadu yang diseleksi menurut panduan-panduan yang ditentukan. Panduan tersebut beragam tergantung pada mata pelajaran dan tujuan portofolio, sedangkan Ahiri dan Hafid ( 2011: 107) mengemukakan bahwa portofolio adalah insrumen penilaian yang digunakan untuk menyajikan hasil karya pilihan dan kemajuan belajar siswa dalam kurun waktu tertentu.

Berdasarkan beberapa pengertian di atas, portofolio sebagai salah satu instrumen penilaian harus mampu mencerminkan hasil belajar atau hasil pekerjaan siswa terhadap sesuatu yang dipelajarinya. Dengan kata lain, penilaian portofolio harus mampu menyajikan hasil pemahaman siswa atas pelajaran yang dipelajarinya sehingga mampu menjadi cerminan kompetensi yang dikuasai pada periode tertentu.

Untuk sampai pada pencapaian yang maksimal sebagai hasil kerja atau cermin 
kompetensi siswa maka proses pembelajaran yang diberikan harus juga sesuai dengan kondisi/karakteristik siswa yang dinilai. Illeris (2011:21) mengemukakan bahwa terdapat beberapa hal yang memengaruhi pembelajaran, di antaranya kondisi internal pembelajaran.

$\begin{array}{lccr}\quad \text { Yang } & \text { dimaksud } & \text { kondisi } & \text { internal } \\ \text { pembelajaran } & \text { menurut } & \text { Illeris } & \text { adalah } \\ \text { karakteristik } & \text { diri pembelajar } & \text { yang }\end{array}$ memengaruhi peluang pembelajaran dan terlibat dalam proses pembelajaran. Mengacu pada pedapat Illeris ini maka gaya belajar sebagai salah satu karakteristik seorang individu tentu menjadi salah satu faktor dalam keberhasilan seseorang untuk menguasai sebuah kompetensi dari hasil belajarnya. Oleh karena itu, portofolio sebagai salah satu instrumen penilaian yang secara komprehensif dapat dijadikan sebagai alat untuk mengukur pencapaian seseorang layak disusun dengan memperhatikan gaya belajar siswa, atau dengan kata lain instrumen portofolio yang berbasis pada gaya belajar siswa layak untuk dikaji. Instrumen berbasis gaya belajar siswa ini diharapkan mampu untuk mengevaluasi aspek kognitif, afektif, dan psikomotor siswa.

\section{JENIS PENILAIAN PORTOFOLIO}

Portofolio memiliki beberapa jenis. Yamin (2011: 281) menggolongkan tiga bentuk portofolio, yaitu: 1) Portofolio perkembangan, berisi koleksi artefak peserta didik yang menunjukkan pertumbuhan seorang peserta didik; 2) portofolio pamer, berisi koleksi artefak peserta didik yang menunjukkan hasil karya terbaiknya; 3) portofolio komprehensif, berisi koleksi artefak seluruh hasil karya peserta didik.

Pendapat lain tentang jenis portofolio dikemukakan Ahiri dan Hafid (2011: 114) yaitu 1) portofolio karya terbaik (portofolio hasil) dan 2) portofolio pertumbuhan dan kemajuan belajar (portofolio proses).

Penggolongan jenis portofolio seperti yang dikemukakan Yamin (2011) serta Ahiri dan Hafid (2011) pada dasarnya memiliki kesamaan, perbedaan antara kedua penggolongan tersebut terletak pada pengategorian. Portofolio perkembangan menurut Yamin pada dasarnya sama dengan portofolio hasil menurut Ahiri dan Hafid. Demikian juga portofolio pamer sama dengan portofolio proses. Oleh karena itu, penulis cenderung bahwa jenis portofolio dapat dikategorikan menjadi dua macam jenis, yaitu portofolio proses belajar dan portofolio hasil belajar.

Portofolio proses belajar sebagaimana dikemukakan oleh Ahiri dan Hafid (2011: 120) digunakan untuk memantau kemajuan belajar dan mendiagnosis kesulitan belajar siswa. Siswa memiliki peranan penting dalam menentukan cakupan isi portofolio dan menggunakannya untuk mengevaluasi sendiri kemajuan belajarnya dalam sebuah proses pembelajaran. Sebagai contoh dalam palajaran Bahasa Indonesia tentang kemajuan kemampuan siswa dalam menyusun sebuah tulisan jenis tertentu dalam waktu tertentu.

Portofolio hasil (hasil karya terbaik) menurut Ahiri dan Hafid (2011: 114) merupakan portofolio yang hanya menyajikan hasil karya terbaik dan terpilih dari seseorang yang disesuaikan dengan tujuan pembelajaran. Untuk mengembangkan portofolio jenis ini berkaitan dengan 1) isi portofolio; 2) cara memilih karya terbaik; 3) kesesuaian isi dengan rubrik penskoran.

Dalam beberapa literatur, terdapat beberapa contoh tugas-tugas siswa yang dikategorikan sebagai evaluasi portofolio. Namun, contoh-contoh tersebut diantaranya belum secara gamblang dapat membedakan antara jenis portofolio proses dengan jenis portofolio hasil. Berikut beberapa contoh hasil kerja siswa yang digolongkan ke dalam jenis portofolio: 1) hasil proyek penyelidikan, atau praktik siswa yang disajikan secara tertulis; 2) hasil kerja siswa dengan menggunakan alat rekam, atau komputer, atau disket; 3) analisis situasi yang berkaitan atau relevan dengan mata pelajaran yang bersangkutan; 4) gambar atau laporan hasil pengamatan; 5) deskripsi dan diagram pemecahan suatu masalah; 6) laporan kerja kelompok; 6) penyelesaian 
soal-saoal terbuka; 7) laporan tentang sikap siswa terhadap pelajaran 8) penghargaan tertulis; dan 9) hasil karya berupa tulisan, ringkasan; 10) laporan kerja kelompok; 11) cerita tentnag kesenangan atau ketidaksenangan; 12) cerita tentang usaha siswa sendiri dalam mengatasi hambatan psikologis, atau usaha peningaktan diri, dalam mempelajari mata pelajaran yang bersangkutan; 13) Hasil karya dalam mata pelajaran yang bersangkutan, yang tidak ditugaskan oleh guru. (Depdiknas, 2004: 34)

Surapranata dan Hatta dalam Soewandi (2006: 36) memberikan contoh dokumen dalam portofolio pada pelajaran bahasa sebagai berikut: 1) catatan observasi guru tentang kemampuan berbicara siswa; 2) tanggapan siswa terhadap cerita/dongeng yang dibacakan guru; 3) daftar dan komentar singkat tentang buku yang telah dibaca; 4) sinopsis bacaan yang dibuat; 5) surat-surat yang dibuat; 6) naskah pidato; 7) karangan bebas (puisi, prosa); 8) laporan kunjungan; 9) tulisan di majalah dinding.

Beberapa contoh portofolio di atas, menurut hemat penulis belum menunjukkan sebuah rangkaian yang merujuk pada proses pencapaian kompetensi siswa dalam satu kompetensi tertentu sehingga diperlukan sebuah pengelompokan yang dapat memperjelas capaian pembelajaran seorang siswa secara terstruktur. Misalnya, untuk menggambarkan capaian kompetensi siswa dalam menulis karangan eksposisi maka portofolionya berupa tulisan -tulisan yang memperlihatkan proses pencapaian kompetensinya dalam menulis sebuah karangan eksposisi (jika jenis portofolio yang diinginkan merupakan jenis portofolio proses).

\section{TUJUAN PORTOFOLIO}

Sebagai instrumen penilaian, portofolio mengandung tujuan untuk mengevaluasi berbagai kompetensi, baik kompetensi kognitif, afektif, dan psikomotor siswa. Sebagaimana dikemukakan Depdiknas (2004: 3) bahwa portofolio harus dapat mencerminkan wawasan banyak tentang segi perkembangan siswa dalam belajarnya: cara berpikir, pemahaman atas pelajaran, kemampuan mengungkapkan gagasangagasan, maupun sikap terhadap mata pelajaran.

Kompetensi kognitif siswa dapat dievaluasi berdasarkan pada jenis kognitif/jenis pengetahuan. Anderson dan Krathwohl (2010: 30) menyusun kategori pengetahuan atas dua hal, yaitu : 1) dimensi pengetahuan dan 2) dimensi proses. Dimensi pengetahuan terdiri atas empat kategori, yaitu: 1) pengetahuan faktual, merupakan pengetahuan tentang elemen-elemen yang terpisah dan mempunyai ciri-ciri tersendiri; 2) pengetahuan konseptual, yaitu pengetahuan tentang bentuk-bentuk pengetahuan yang lebih kompleks dan terorganisasi; 3) pengetahuan prosedural, yaitu pengetahuan bagaimana melakukan sesuatu; dan 4) pengetahuan metakognitif, yaitu pengetahuan mengenai kognisi secara umum, kesadaran akan dan pengetahuan mengenai kognisi sendiri.

Dimensi proses terdiri atas: 1) mengingat/mengambil pengetahuan dari memori jangka panjang: mengenali dan mengingat kembali; 2 ) memahami/mengkonstruksi makna dari materi pembelajaran, termasuk apa yang diucapkan, ditulis, dan digambar oleh guru: menafsirkan, mencontohkan, mengklasifikasikan, merangkum, menyimpulkan, membandingkan, menjelaskan; 3) mengaplikasikan/ menerapkan atau menggunakan suatu prosedur dalam keadaan tertentu: mengeksekusi, mengimplementasikan; 4) menganalisis/memecah-mecah materi menjadi bagian-bagian: membedakan, mengorganisasi, mengatribusikan; 5) mengevaluasi/mengambil keputusan berdasarkan kriteria dan/atau standar: memeriksa, mengkritik; 6) mencipta/ memadukan bagian-bagian untuk membentuk sesuatu yang baru dan koheren atau untuk membeuat sesuatu yang orisinal.: merumuskan, merencanakan, memproduksi.

Kompetensi afektif dapat dievaluasi berdasarkan pada jenjang afektif yang 
meliputi: 1) receiving/menerima; 2) responding/merespon;

valuing/menghargai;

organization/mengorganisasikan; characterization/mengkarakterisasikan. (Kemdikbud: 2013).

Kompetensi psikomotor/ skill dapat dievaluasi berdasarkan pada jenjang psikomotor sebagaimana dikemukakan oleh Harrow (Rahyubi, 2012: 294) yang meliputi: 1) gerakan refleks, yaitu gerak tanpa disadari; 2) gerakan dasar, merupakan pola gerakan yang menjadi dasar meraih keterampilan gerak yang lebih kompleks; 3) kemampuan mengamati, yaitu kemampuan dalam mempersepsi sesuatu secara baik dan akurat yang terdiri atas persepsi visual, persepsi auditif, persepsi kinestetik, persepsi taktil, dan persepsi koordinasi; 3) kemampuan fisik, kemampuan motorik untuk meraih keterampilan, antara lain: stabilitas dan keseimbangan, daya tahan, kekuatan, kelincahan, dan kelenturan; 5) gerakan keterampilan, yaitu gambaran kemampuan motorik seseorang yang ditunjukkan melalui penguasaan suatu gerakan. Siswa diharapkan mampu menguasai keterampilan motorik, misalnya melakukan suatu tugas gerak secara maksimal sesuai dengan kemampuannya; 6) kemampuan komunikatif, yaitu kemampuan berkomunikasi dengan menggunakan gerakan, misalnya gerakan ekspresif dan gerakan interpretatif.

Berdasarkan ketiga ranah kompetensi yang harus dikuasai siswa tersebut, penyusunan portofolio pun harus mencakup ketiga ranah tersebut. Oleh karena itu, instrumen portofolio untuk menilai kompetensi kognitif dapat dilakukan dengan memberikan tugas-tugas berupa soal-soal yang harus diselesaikan melalui proses kognitif. Untuk mengukur kompetensi afektif, instrumen dapat disusun berupa lembar pengamatan atau observasi. Demikian juga untuk menilai kompetensi psikomotor.

\section{GAYA BELAJAR SISWA}

Pengertian gaya belajar menurut Brown (2008: 127) adalah karakteristik umum kerja intelektual (dan jenis kepribadian juga) yang berkaitan dengan seseorang sebagai individu dan yang membedakannya dengan orang lain. Yang dimaksud dengan gaya belajar di sini merupakan kecenderungan seseorang dalam memperoleh informasi (belajar) berdasarkan indera penerimanya.

Istilah yang digunakan Joice dan Weil berkaitan dengan model belajar seseorang adalah model pribadi (personal) meskipun dalam hal ini Joice mengategorikannya sebagai model mengajar. Namun dapat disejajarkan dengan gaya belajar sebagaimana yang dikemukakan Brown. Joyce dan Weil (Wikanengsih, 2012) meninjau segi model pembelajaran,- model pembelajran pada hakikatnya tidak berbeda jauh dengan model belajar, mengemukakan bahwa model pembelajaran dikelompokkan menjadi empat, yaitu: 1) model memproses informasi. Model ini menitikberatkan pada kemampuan kognitif siswa dalam memproses informasi selama proses belajar berlangsung; 2) model pribadi (personal), yaitu penekanannya pada individu masing-masing siswa dalam mengembangkan dirinya dalam lingkungan sehingga pribadinya dipengaruhi oleh faktor lingkungan sosialnya;

3) model interaksi sosial, menekankan pada hubungan sosial dan perorangan di antara individu sehingga siswa bisa berinteraksi dengan orang lain dalam lingkungannya. 4) model perilaku, menekankan pada perubahan perilaku siswa sebagai akibat dari belajar.

Kaitannya dalam gaya pembelajaran bahasa, Brown (2008: 129) mengemukakan sejumlah gaya pembelajaran bahasa, yaitu: 1) dependensi-independensi bidang; yang dimaksud depensi bidang adalah kecenderungan untuk tergantung pada bidang total sehingga bagian-gaian yang melekat dalam bidang-bidang itu tidak mudah dikenali, sedangkan indepensi bidang sebaliknya; 2) acak-linear; 3) umum-khusus; 4) induktif-deduktif; 5) sintesis-analitis; 6) analog-digital; 7) konkret-abstrak; 8) penyetaraan-penajaman; 9) impulsif-reflektif, dan 10) visual, auditoris, dan kinestetis yang dipaparkannya dalam halaman yang terpisah (Brown,2008:138). Adanya perbedaan gaya 
belajar dalam diri seseorang (peserta didik) mestinya dapat dimanfaatkan oleh guru dalam proses belajarnya sehingga peserta didik dapat mengoptimalkan gaya belajarnya terhadap hasil belajar yang akan dicapai.

Berdasarkan kesepuluh macam gaya pembelajaran sebagaimana diungkapkan Brown di atas, penilaian pembelajaran dengan menggunakan portofolio dalam tulisan ini menyangkut tentang gaya belajar seseorang jenis ke-10, yaitu gaya visual, auditori dan kinestetis. Gaya belajar yang pertama, visual, yaitu kecenderungan seseorang dalam memahami sesuatu banyak melibatkan indera penglihatan, misalnya menyukai tabel, gambar dan informasi grafis lainnya. Gaya belajar yang ke dua auditori yaitu kecenderungan seseorang dalam memahami sesuatu melalui indera pendengaran. Tipe anak yang memiliki gaya belajar auditori dapat mencerna makna disampaikan melalui nada suara, tinggirendahnya , cepat-lambatnya berbicara. Gaya belajar yang ketiga kinestetis yaitu kecenderungan seseorang dalam memahami sesuatu melalui demonstrasi atau pergerakan anggota badan (bergerak, bekerja, dan menyentuh).

Strategi untuk membantu proses belajar bagi peserta didik yang memiliki gaya belajar visual, auditori dan kinestetis seperti yang dikemukakan Thobroni dan Mustofa (2011: 263) sebagai berikut: a) untuk siswa visual: 1) gunakan materi visual, seperti gambar, diagram, dan peta; 2) gunakan warna untuk menandai hal-hal yang penting; 3) ajak anak untuk membaca buku berilustrasi; 4) gunakan multimedia; 5) ajak anak untuk mencoba mengilustrasikan ide-idenya ke dalam gambar. b) Strategi untuk membantu belajar siswa yang memiliki gaya belajar auditori melalui: 1) ajak anak untuk ikut berpartisipasi dalam diskusi, baik di dalam kelas maupun di luar kelas; 2) dorong anak untuk membaca materi pelajaran dengan keras; 3) gunakan musik untuk mengajarkan anak; 4) diskusikan ide anak secara verbal; 5) biarkan anak untuk merekan materi pelajaran. c) Strategi untuk siswa yang memiliki gaya belajar kinestetis; 1) jangan paksakan anak untuk belajar sampai berjam-jam; 2) ajak anak untuk belajar sambil mengeksplorasi lingkungannya; 3) ijinkan anak untuk mengunyah permen; 4) biarkan anak belajar sambil menggerakkan anggota tubuhnya atau berjalan-jalan.

Proses belajar dengan memperhatikan gaya belajar setiap individu diharapkan dapat memaksimalkan pencapaian hasil belajar siswa. Untuk mengetahui hasil belajar yang dicapai setiap siswa tentu harus dilakukan melakukan evaluasi. Evaluasi fortofolio merupakan alat evaluasi yang dapat merekam hasil pencapaian belajar siswa secara intensif dan menyeluruh.

\section{A. Penilaian Portofolio Berbasis Gaya Belajar Siswa}

Untuk menyusun portofolio berbasis gaya belajar siswa dalam mata pelajaran Bahasa Indonesia, berikut dipaparkan langkah-langkah yang dapat ditempuh. Langkah-langkah penyusunan mengacu pada pedoman yang dikeluarkan Depdiknas tahun 2004 dan Ahiri \& Hafid tahun 2011.

1) Menentukan fokus dan tujuan portofolio, misalnya untuk mencapai tujuan kurikulum dan target belajar.

2) Menyesuaikan isi portofolio dengan tujuan pembelajaran. Menentukan aspek isi yang dinilai, misalnya aspek kognitif, afektif, dan psikomotor; untuk menilai pertumbuhan dan kemajuan belajar siswa atau untuk menilai hasil karya terbaik.

3) Menentukan bentuk, susunan, atau organisasi portofolio (teknik pengelolaan portofolio): jenis/aspek data yang akan dievaluasi, isi/indikator, proses, batas isi/waktu penyusunan portofolio.

4) Melibatkan siswa dalam proses penilaian.

5) Meningkatkan efisiensi pemeriksanaan portofolio: menyiapkan rubrik penilaian/penskoran.

6) Meningkatkan ketergeneralisasian skor portofolio.

Keenam langkah penyusunan portofolio di atas dilakukan secara terstruktur, disesuaikan dengan tiga macam gaya belajar siswa. Sebelumnya guru harus mengetahui jenis-jenis gaya belajar siswa dalam kelas. Untuk mengetahui jenis gaya belajar setiap siswa dapat dilakukan melalui tes. Tes dapat dilakukan dengan cara bekerjasama dengan 
guru Bimbingan Konseling atau menggunakan instrumen pengenalan gaya belajar yang valid atau yang terdapat pada situs-situs psikologi yang terpercaya.

Untuk menyusun portofolio siswa yang memiliki gaya belajar visual dalam mencapai kompetensi tertentu, tugas-tugas yang diberikan disesuaikan dengan gaya belajarnya, misalnya melalui kegiatankegiatan yang berhubungan dengan indera penglihatan, seperti membaca buku, membaca tabel, dll. Bagi siswa yang memiliki gaya belajar auditori, tugas yang diberikan berupa tugas atau kegiatan yang berhubungan dengan indera pendengaran, misalnya melalui menyimak berita di televisi atau radio. Demikian juga, bagi siswa yang memiliki gaya belajar kinestetik, tugas yang harus diselesaikan berhubungan dengan kegiatan yang berhubungan dengan aktivitas motorik, misalnya melaporkan hasil perjalanan/rekreasi ke suatu tempat. Pemberian tugas-tugas yang disesuaikan dengan masing-masing gaya belajar siswa diharapkan dapat mengoptimalkan pencapaian kompetensinya.
Meskipun

dalam mengimplementasikan Kurikulum 2013, kegiatan guru dan siswa, bahan ajar, serta sistem evaluasi telah tersaji dengan lengkap dalam buku guru dan buku siswa, namun guru masih memiliki kesempatan untuk mengembangkan proses pembelajaran berikut evaluasinya berdasarkan pada kreativitas guru karena sebagaimana diungkapkan Mendikbud pada sosialisasi Kurikulum 2013 bahwa buku guru dan buku siswa yang telah disediakan pemerintah merupakan panduan dasar atau batas minimal pelaksanaan pembelajaran yang dilakukan guru di lapangan. Evaluasi melalui penilaian portofolio berbasis gaya belajar siswa dapat dikembangkan guru, disesuaikan dengan tujuan yang terdapat dalam kurikulum.

Berikut contoh penyusunan penilaian portofolio berbasis gaya belajar pada mata pelajaran Bahasa dan Sastra Indonesia berdasarkan Kurikulum 2013 untuk tingkat SMA dengan kompetensi dasar dan indikator seperti tampak dalam tabel 1. di bawah ini.

Tabel 1. Kompetensi Dasar dan Indikator

\begin{tabular}{|c|c|c|c|c|}
\hline \multirow[t]{2}{*}{ Kompetensi dasar } & \multirow[t]{2}{*}{ Indikator } & \multicolumn{3}{|c|}{$\begin{array}{c}\text { Jenis Portofolio: Perkembangan } \\
\text { Kompetensi Siswa }\end{array}$} \\
\hline & & Visual & Auditori & Kinestetik \\
\hline $\begin{array}{l}1.1 \text { Mensyukuri } \\
\text { anugerah Tuhan } \\
\text { akan keberadaan } \\
\text { bahasa Indonesia } \\
\text { dan } \\
\text { menggunakannya } \\
\text { sesuai dengan } \\
\text { kaidah dan konteks } \\
\text { untuk } \\
\text { mempersatukan } \\
\text { bangsa. }\end{array}$ & $\begin{array}{l}\text { 1.1Menyampaikan } \\
\text { secara lisan dan } \\
\text { tulis kejadian sosial } \\
\text { di masyarakat dan } \\
\text { alam sekitar dalam } \\
\text { teks laporan hasil } \\
\text { observasi dengan } \\
\text { tahapan yang benar: } \\
\text { pertanyaan } \\
\text { klasifikasi, } \\
\text { deskripsi bagian, } \\
\text { tujuan, fungsi, } \\
\text { kegunaan, dll. }\end{array}$ & $\begin{array}{l}\text { Melaporkan } \\
\text { hasil } \\
\text { observasi dari } \\
\text { kegiatan } \\
\text { membaca } \\
\text { buku tentang } \\
\text { keadaan alam } \\
\text { sekitar }\end{array}$ & $\begin{array}{l}\text { Melaporkan } \\
\text { hasil } \\
\text { observasi dari } \\
\text { kegiatan } \\
\text { mendengarkan } \\
\text { tentang alam } \\
\text { sekitar }\end{array}$ & $\begin{array}{l}\text { Melaporkar } \\
\text { hasil } \\
\text { observasi } \\
\text { dari } \\
\text { kegiatan } \\
\text { mengujung } \\
\text { tempat } \\
\text { tertentu }\end{array}$ \\
\hline
\end{tabular}

Penerapan langkah penyusunan instrumen penilaian portofolio:

Langkah ke-1: untuk menilai kompetensi siswa dalam menulis laporan hasil observasi.
Langkah ke-2: mengevaluasi pengetahuan, sikap dan psikomotor.

Contoh tugas yang diberikan kepada siswa berupa evaluasi perkembangan kompetensi menulis hasil laporan observasi. 
1. Untuk siswa yang memiliki gaya belajar visual.

Buatlah laporan hasil observasi dari kegiatan membaca buku tentang alam sekitar

(laporan terdiri atas 500 buah kata)

2. Untuk siswa yang memiliki gaya belajar auditori

Buatlah laporan hasil observasi dari kegiatan mendengarkan tentang alam sekitar/mendengarkan berita dari radio atau televisi. (laporan terdiri atas 500 buah kata)

3. Untuk siswa yang memiliki gaya belajar kinestetik

Buatlah laporan hasil observasi dari kegiatan mengunjungi tempat wisata. (laporan terdiri atas 500 buah kata)

Langkah ke-3: Menentukan bentuk, susunan, atau organisasi portofolio (teknik pengelolaan portofolio): jenis/aspek data yang akan dievaluasi, indikator, proses, batas isi/waktu penyusunan portofolio.

Tabel 2. Jenis Unjuk Kerja untuk Menilai setiap Kategori Kemampuan

\begin{tabular}{|c|c|c|c|}
\hline \multicolumn{2}{|c|}{ Aspek yang Divaluasi } & \multirow[t]{2}{*}{ Indikator } & \multirow[t]{2}{*}{ Evaluasi/Penilaian } \\
\hline \multirow{5}{*}{ Kognitif } & Dimensi Kognitif & & \\
\hline & $\begin{array}{ll}\text { a. } & \text { Pengetahuan } \\
\text { Faktual }\end{array}$ & $\begin{array}{l}\text { Mengingat pengertian } \\
\text { teks laporan }\end{array}$ & $\begin{array}{l}\text { Meminta siswa untuk } \\
\text { menuliskan pengertian teks } \\
\text { laporan hasil observasi }\end{array}$ \\
\hline & $\begin{array}{l}\text { b. Pengetahuan } \\
\text { Konseptual }\end{array}$ & $\begin{array}{l}\text { Mengetahui stuktur teks } \\
\text { laporan }\end{array}$ & $\begin{array}{l}\text { Meminta siswa untuk } \\
\text { menjelaskan struktur teks } \\
\text { laporan hasil observasi }\end{array}$ \\
\hline & $\begin{array}{l}\text { c. Pengetahuan } \\
\text { Prosedural }\end{array}$ & $\begin{array}{l}\text { Mampu menjelaskan } \\
\text { bagaimana menyusun } \\
\text { teks laporan }\end{array}$ & $\begin{array}{l}\text { Meminta siswa untuk } \\
\text { menjelaskan langkah- } \\
\text { langkah dalam menyusun } \\
\text { teks laporan hasil observasi }\end{array}$ \\
\hline & $\begin{array}{l}\text { d. Pengetahuan } \\
\text { Metakognitif }\end{array}$ & $\begin{array}{l}\text { Mampu menilai } \\
\text { kemampuan diri sendiri } \\
\text { dalam menulis teks } \\
\text { laporan }\end{array}$ & $\begin{array}{l}\text { Meminta siswa menilai diri } \\
\text { sendiri berdasarkan format } \\
\text { evaluasi diri. (Tabel } 4 \text { ) }\end{array}$ \\
\hline \multirow{8}{*}{$\begin{array}{l}\text { Sikap } \\
\text { /Karakter }\end{array}$} & \multirow[t]{4}{*}{ Bersahabat } & $\begin{array}{l}\text { Bekerjasama dalam } \\
\text { kelompok di kelas }\end{array}$ & \multirow[t]{4}{*}{$\begin{array}{l}\text { Dilakukan guru melalui } \\
\text { pengamatan. (Tabel 3) }\end{array}$} \\
\hline & & $\begin{array}{l}\text { Berbicara dengan teman } \\
\text { di kelas }\end{array}$ & \\
\hline & & $\begin{array}{l}\text { Bergaul dengan teman } \\
\text { sekelas ketika } \\
\text { beristirahat }\end{array}$ & \\
\hline & & $\begin{array}{l}\text { Berbicara dengan guru, } \\
\text { kepala sekolah, dan } \\
\text { personalia sekolah } \\
\text { lainnya }\end{array}$ & \\
\hline & \multirow[t]{3}{*}{ Toleran } & $\begin{array}{l}\text { Tidak mengaganggu } \\
\text { teman yang berbeda } \\
\text { penddapat }\end{array}$ & \multirow[t]{3}{*}{$\begin{array}{l}\text { Dilakukan guru melalui } \\
\text { pengamatan. (Tabel 3) }\end{array}$} \\
\hline & & $\begin{array}{l}\text { Menghormati teman } \\
\text { yang berbeda adat- } \\
\text { istiadatnya }\end{array}$ & \\
\hline & & $\begin{array}{l}\text { Bersahabat dengan } \\
\text { teman dari kelas lain }\end{array}$ & \\
\hline & Kerja keras & $\begin{array}{l}\text { Mengerjakan semua } \\
\text { tugas kelas selesai } \\
\text { dengan baik pada waktu }\end{array}$ & $\begin{array}{l}\text { Dilakukan guru melalui } \\
\text { pengamatan. (Tabel 3) }\end{array}$ \\
\hline
\end{tabular}




\begin{tabular}{|c|c|c|c|}
\hline \multicolumn{2}{|c|}{ Aspek yang Divaluasi } & \multirow{2}{*}{$\begin{array}{c}\text { Indikator } \\
\text { yang telah ditetapkan }\end{array}$} & \multirow[t]{4}{*}{ Evaluasi/Penilaian } \\
\hline & & & \\
\hline & & $\begin{array}{l}\text { Tidak putus asa dalam } \\
\text { menghadapi kesulitan } \\
\text { dalam belajar }\end{array}$ & \\
\hline & & $\begin{array}{l}\text { Selalu fokus pada } \\
\text { pelajaran }\end{array}$ & \\
\hline & \multirow[t]{2}{*}{ Kreatif } & $\begin{array}{l}\text { Mengajukan pendapat } \\
\text { yang berkenaan dengan } \\
\text { suatu pokok kebiasaan }\end{array}$ & \multirow[t]{2}{*}{$\begin{array}{l}\text { Dilakukan guru melalui } \\
\text { pengamatan. (Tabel 3) }\end{array}$} \\
\hline & & $\begin{array}{l}\text { Bertanya mengenai } \\
\text { penerapan suatu } \\
\text { hukum.teori/prinsip dari } \\
\text { materi lain ke materi } \\
\text { yang sedang dipelajari }\end{array}$ & \\
\hline Psikomotor & Komunikatif & $\begin{array}{l}\text { Mampu menyajikan } \\
\text { teks laporan baik lisan } \\
\text { maupun tulisan }\end{array}$ & $\begin{array}{l}\text { Meminta siswa menyusun } \\
\text { teks laporan hasil observasi } \\
\text { secara lisan atau tulis. } \\
\text { (Prosedur penyusunan tugas } \\
\text { disesuaikan dengan gaya } \\
\text { belajar setiap siswa. Lihat } \\
\text { pada contoh tugas langkah } \\
\text { ke-2) }\end{array}$ \\
\hline
\end{tabular}

Tabel 3. Instrumen Penilaian Sikap/Karakter

\begin{tabular}{|c|c|c|c|c|c|c|c|}
\hline No & Sikap & Deskripsi & Indikator & BT & MT & MB & MK \\
\hline \multirow[t]{4}{*}{1.} & \multirow[t]{4}{*}{$\begin{array}{l}\text { Bersahabat/ } \\
\text { komunikatif }\end{array}$} & \multirow{4}{*}{$\begin{array}{l}\text { Tindakan yang } \\
\text { memperlihatkan } \\
\text { rasa senang } \\
\text { berbicara, } \\
\text { bergaul, dan } \\
\text { bekerja sama } \\
\text { dengan orang lain }\end{array}$} & $\begin{array}{l}\text { Bekerjasama dalam } \\
\text { kelompok di kelas }\end{array}$ & & & & \\
\hline & & & $\begin{array}{l}\text { Berbicara dengan } \\
\text { teman di kelas }\end{array}$ & & & & \\
\hline & & & $\begin{array}{l}\text { Bergaul dengan teman } \\
\text { sekelas ketika } \\
\text { beristirahat }\end{array}$ & & & & \\
\hline & & & $\begin{array}{l}\text { Berbicara dengan } \\
\text { guru, kepala sekolah, } \\
\text { dan personalia sekolah } \\
\text { lainnya }\end{array}$ & & & & \\
\hline \multirow[t]{3}{*}{2.} & \multirow[t]{3}{*}{ Toleransi } & \multirow{3}{*}{$\begin{array}{l}\text { Sikap dan } \\
\text { tindakan yang } \\
\text { menghargai } \\
\text { perbedaan agama, } \\
\text { suku, etnis, } \\
\text { pendapat, sikap, } \\
\text { dan tindakan } \\
\text { orang lain yang } \\
\text { berbeda dengan } \\
\text { dirinya }\end{array}$} & $\begin{array}{l}\text { Tidak mengaganggu } \\
\text { teman yang berbeda } \\
\text { penddapat }\end{array}$ & & & & \\
\hline & & & $\begin{array}{l}\text { Menghormati teman } \\
\text { yang berbeda adat- } \\
\text { istiadatnya }\end{array}$ & & & & \\
\hline & & & $\begin{array}{l}\text { Bersahabat dengan } \\
\text { teman dari kelas lain }\end{array}$ & & & & \\
\hline 3. & Kerja Keras & $\begin{array}{l}\text { Perilaku yang } \\
\text { menunjukkan aya } \\
\text { sungguh-sungguh } \\
\text { dalam mengatasi }\end{array}$ & $\begin{array}{l}\text { Mengerjakan semua } \\
\text { tugas kelas selesai } \\
\text { dengan baik pada } \\
\text { waktu yang telah }\end{array}$ & & & & \\
\hline
\end{tabular}




\begin{tabular}{|c|c|c|c|c|c|c|c|}
\hline No & Sikap & Deskripsi & Indikator & BT & MT & MB & MK \\
\hline & & \multirow{3}{*}{$\begin{array}{l}\text { berbagai } \\
\text { hambatan belajar, } \\
\text { tugas, dan } \\
\text { menyelesaikan } \\
\text { tugas dengan } \\
\text { sebaik-baiknya. }\end{array}$} & ditetapkan & & & & \\
\hline & & & $\begin{array}{l}\text { Tidak putus asa dalam } \\
\text { menghadapi kesulitan } \\
\text { dalam belajar }\end{array}$ & & & & \\
\hline & & & $\begin{array}{l}\text { Selalu fokus pada } \\
\text { pelajaran }\end{array}$ & & & & \\
\hline \multirow[t]{2}{*}{4.} & \multirow[t]{2}{*}{ Kreatif } & \multirow{2}{*}{$\begin{array}{l}\text { Berpikir dan } \\
\text { melakukan } \\
\text { sesuatu yang } \\
\text { menghasilkan } \\
\text { cara atau hasil } \\
\text { baru dari yang } \\
\text { telah dimiliki }\end{array}$} & $\begin{array}{l}\text { Mengajukan pendapat } \\
\text { yang berkenaan } \\
\text { dengan suatu pokok } \\
\text { kebiasaan }\end{array}$ & & & & \\
\hline & & & $\begin{array}{l}\text { Bertanya mengenai } \\
\text { penerapan suatu } \\
\text { hukum.teori/prinsip } \\
\text { dari materi lain ke } \\
\text { materi yang sedang } \\
\text { dipelajari }\end{array}$ & & & & \\
\hline
\end{tabular}

Keterangan:

BT = Belum Terlihat

MT = Mulai Terlihat

MB = Mulai Berkembang

MK = Membudaya

Diadopsi dari Wikanengsih (2012)

\section{Langkah ke-4: Melibatkan Siswa dalam Proses Penilaian}

Tabel 4. Lembar Evaluasi Diri Siswa

\begin{tabular}{|c|c|c|c|}
\hline \multirow{2}{*}{$\begin{array}{c}\text { Aspek yang Dinilai dari Laporan Hasil } \\
\text { Observasi }\end{array}$} & \multicolumn{3}{|c|}{ Hasil Penilaian Siswa } \\
\hline & & & \\
\hline Isi tulisan sesuai dengan judul & $\mathrm{Ya}$ & Netral & Tidak \\
\hline \multicolumn{4}{|l|}{ Tersusun secara logis } \\
\hline \multicolumn{4}{|l|}{ Menggunakan kalimat lengkap } \\
\hline \multicolumn{4}{|l|}{ Penulisan katanya tepat } \\
\hline \multicolumn{4}{|l|}{ Sumber kutipan jelas } \\
\hline \multicolumn{4}{|l|}{ Pembahasannya lengkap } \\
\hline \multicolumn{4}{|l|}{ Simpulannya jelas } \\
\hline \multicolumn{4}{|l|}{ Ada daftar pustaka } \\
\hline \multicolumn{4}{|c|}{ 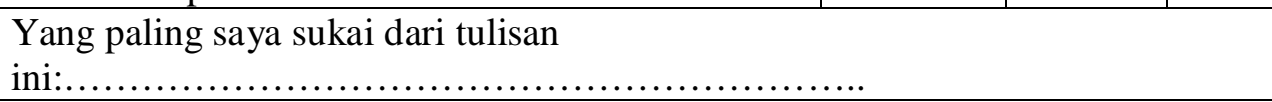 } \\
\hline \multicolumn{4}{|c|}{$\begin{array}{l}\text { Masalah utama yang saya alami ketika menulis tulisan } \\
\text { ini:............................ }\end{array}$} \\
\hline \multicolumn{4}{|c|}{ 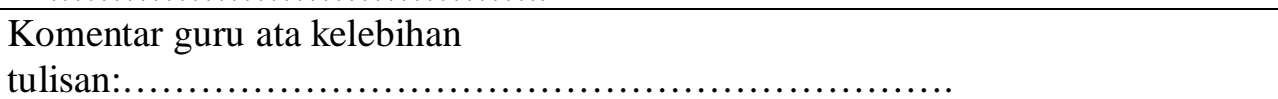 } \\
\hline $\begin{array}{l}\text { Komentar guru atas kekurangan } \\
\text { tulisan:......................... }\end{array}$ & & & \\
\hline
\end{tabular}

Dikutip dari Ahiri dan Hafid (2011: 130)

Langkah ke-5: Meningkatkan efisiensi pemeriksaaan portofolio: menyiapkan rubrik penilaian/penskoran. 
Tabel 5. Rubrik Penilaian Aspek Kognitif

\begin{tabular}{|c|l|c|c|l|c|}
\hline No & $\begin{array}{c}\text { Indikator Pencapaian } \\
\text { Kompetensi Kognitif }\end{array}$ & $\begin{array}{c}\text { Teknik } \\
\text { Penilaian }\end{array}$ & $\begin{array}{c}\text { Bentuk } \\
\text { Penilaian }\end{array}$ & \multicolumn{1}{|c|}{ Instrumen } & Skor \\
\hline 1. & $\begin{array}{l}\text { Mengingat pengertian } \\
\text { teks laporan }\end{array}$ & $\begin{array}{c}\text { Tes } \\
\text { tertulis }\end{array}$ & Tes uraian & $\begin{array}{l}\text { Tuliskan } \\
\text { pengertian teks } \\
\text { laporan }\end{array}$ & 1 \\
\hline 2. & $\begin{array}{l}\text { Mengetahui stuktur teks } \\
\text { laporan }\end{array}$ & $\begin{array}{c}\text { Tes } \\
\text { tertulis }\end{array}$ & Tes uraian & $\begin{array}{l}\text { Jelaskan struktur } \\
\text { teks laporan }\end{array}$ & 2 \\
\hline 3. & $\begin{array}{l}\text { Mampu menjelaskan } \\
\text { bagaimana menyusun } \\
\text { teks laporan }\end{array}$ & $\begin{array}{c}\text { Tes } \\
\text { tertulis }\end{array}$ & Tes uraian & $\begin{array}{l}\text { Jelaskan langkah- } \\
\text { langkah dalam } \\
\text { menyusun teks } \\
\text { laporan }\end{array}$ & 2 \\
\hline
\end{tabular}

Tabel 6. Rubrik Penilaian Teks Laporan Hasil Observasi

\begin{tabular}{|c|c|c|c|}
\hline & Skor & Kriteri & Komentar \\
\hline \multirow{4}{*}{$\bar{\Omega}$} & $27-30$ & $\begin{array}{lr}\text { Sangat baik-sempurna: } & \text { menguasai } \\
\text { topik tulisan; substantif; pengembangan } \\
\text { pernyataan umum atau } \\
\text { klasifikasi^anggota/aspek yang } \\
\text { dilanorkan cenara lenolen. relavan }\end{array}$ & \\
\hline & $22-26$ & $\begin{array}{llr}\text { Cukup-baik: cukup menguasai } \\
\text { permasalahan; } & \text { cukup memadai; } \\
\text { pengembangan } & \text { tesis terbatas: relevan }\end{array}$ & \\
\hline & $17-21$ & $\begin{array}{l}\text { Sedang-cukup: } \\
\text { permasalahan terbatas; } \\
\text { kurang; substansi } \\
\end{array}$ & \\
\hline & $13-16$ & $\begin{array}{l}\text { Sangat kurang-kurang: tidak } \\
\text { menguasai permasalahan; tidak ada } \\
\text { substansi: tidak relevan: tidak lavak }\end{array}$ & \\
\hline \multirow{4}{*}{ 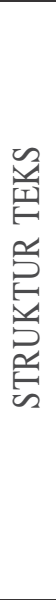 } & $18-20$ & $\begin{array}{l}\text { Sangat baik-sempurna: ekspresi } \\
\text { lancar; gagasan terungkap padat } \\
\text { dengan jelas; tertata dengan baik; } \\
\text { urutan logis (pernyataan umum atau } \\
\text { klacifikaci^anoonta/acnel. }\end{array}$ & \\
\hline & $14-17$ & $\begin{array}{l}\text { Cukup_baik: kurang lancar; kurang } \\
\text { terorganisasi, tetapi ide utama } \\
\text { ternvatakan; pendukung terbatas: logis. }\end{array}$ & \\
\hline & $10-13$ & $\begin{array}{l}\text { Sedang-cukup: tidak lancar; gagasan } \\
\text { kacau atau tidak terkait; urutan dan } \\
\text { pengembangan kurang logis }\end{array}$ & \\
\hline & $7-9$ & $\begin{array}{l}\text { Sangat kurang-kurang: tidak } \\
\text { komunikatif; }\end{array}$ & \\
\hline
\end{tabular}




\begin{tabular}{|c|c|c|}
\hline \multirow{4}{*}{ 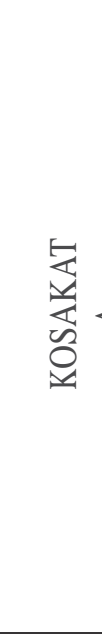 } & $\begin{array}{l}18- \\
20\end{array}$ & $\begin{array}{l}\text { Sangat baik-sempurna: penguasaan } \\
\text { kata canggih; pilihan kata dan ungkapan } \\
\text { efektif; menguasai pembentukan kata; } \\
\text { nenogunaan reoister tenat }\end{array}$ \\
\hline & $\begin{array}{l}14- \\
17\end{array}$ & $\begin{array}{l}\text { Cukup_baik: penguasaan kata } \\
\text { memadai; pilihan, bentuk, dan } \\
\text { penggunaan kata/ungkapan kadang- }\end{array}$ \\
\hline & $\begin{array}{l}10- \\
13\end{array}$ & $\begin{array}{lr}\text { Sedang-cukup: penguasaan kata } \\
\text { terbatas; sering terjadi kesalahan bentuk, } \\
\text { pilihan, dan } \\
\text { kosakata/unokanan. }\end{array}$ \\
\hline & $7-9$ & $\begin{array}{l}\text { Sangat kurang-kurang: pengetahuan } \\
\text { tentang kosakata, ungkapan, dan } \\
\text { pembentukan kata rendah; tidak layak }\end{array}$ \\
\hline \multirow{4}{*}{ 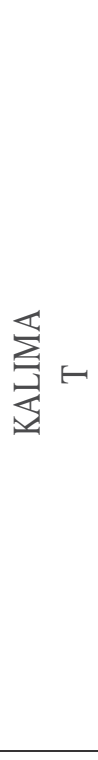 } & $\begin{array}{l}18- \\
20\end{array}$ & $\begin{array}{l}\text { Sangat baik-sempurna: konstruksi } \\
\text { kompleks dan efektif; terdapat hanya } \\
\text { sedikit kesalahan penggunaan bahasa } \\
\text { (urutan/fungsi kata artikel nronomina. }\end{array}$ \\
\hline & $\begin{array}{l}14- \\
17\end{array}$ & $\begin{array}{l}\text { Cukup-baik: konstruksi sederhana, } \\
\text { tetapi efektif; terdapat kesalahan kecil } \\
\text { pada konstruksi kompleks; terjadi } \\
\text { sejumlah kesalahan penggunaan bahasa } \\
\text { (funnos/urutan kata artikel nronomina }\end{array}$ \\
\hline & $\begin{array}{l}10- \\
13\end{array}$ & $\begin{array}{lrr}\text { Sedang-cukup: terjadi } & \text { kesalahan } \\
\text { serius dalam konstruksi } & \text { kalimat } \\
\text { tunggal/kompleks } & \text { (sering } & \text { terjadi } \\
\text { kesalahan pada kalimat negasi, urutan/ } \\
\text { funoci kato artikel nronomins }\end{array}$ \\
\hline & $7-9$ & $\begin{array}{l}\text { Sangat kurang-kurang: } \text { tidak } \\
\text { menguasai tata kalimat; terdapat banyak } \\
\text { kesalahan; tidak komunikatif; tidak layak }\end{array}$ \\
\hline \multirow{4}{*}{ 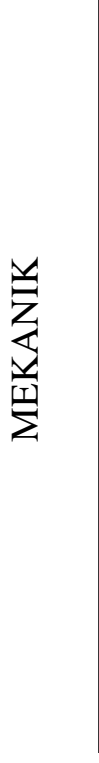 } & $9-10$ & $\begin{array}{l}\text { Sangat baik-sempurna: menguasai } \\
\text { aturan penulisan; terdapat sedikit } \\
\text { kesalahan ejaan, tanda baca, } \\
\text { nenogunaan huruf kanital dan nenataan }\end{array}$ \\
\hline & $7-8$ & $\begin{array}{l}\text { Cukup_baik: kadang-kadang terjadi } \\
\text { kesalahan ejaan, tanda baca, penggunaan } \\
\text { huruf kapital, dan penataan paragraf, tetapi } \\
\text { tidak mengaburkan makna }\end{array}$ \\
\hline & $4-6$ & $\begin{array}{l}\text { Sedang-cukup: sering terjadi } \\
\text { kesalahan ejaan, tanda baca, } \\
\text { penggunaan huruf kapital, dan penataan } \\
\text { naraoraf twlisan tangan tidak ielas: makna }\end{array}$ \\
\hline & $1-3$ & $\begin{array}{l}\text { Sangat kurang-kurang: } r \text { tidak } \\
\text { menguasai aturan penulisan; terdapat } \\
\text { banyak kesalahan ejaan, tanda baca, } \\
\text { penggunaan huruf kapital, dan penataan }\end{array}$ \\
\hline
\end{tabular}

Sumber: Buku Guru Bahasa Indonesia SMA Kurikulum 2013: Depdikbud

Langkah ke-6: $\quad$ Meningkatkan ketergeneralisasian skor portofolio. Langkah 
ini dilakukan dengan memperhatikan cara merumuskan tujuan portofolio secara rinci dan menetapkan teknik pemberian skor terhadap setiap tujuan pembelajaran yang dinilai, misalnya daftar cek dan rubrik penskoran. (Ahiri dan Hafid, 2011: 133). Dalam artikel ini sudah dilakukan.

\section{SIMPULAN}

Pemberlakuan Kurikulum 2013 yang mengandung empat perubahan dalam standar kompetensi lulusan, standar isi, standar proses dan standar penilaian berimbas pada kompetensi yang harus dimiliki guru dalam menyusun perangkat pembelajaran. Perangkat pembelajaran untuk memenuhi perubahan pada standar penilaian menjadikan portofolio sebagai instrumen utama. Oleh karena itu, pengkajian terhadap penyusunan instrumen portofolio diperlukan dari berbagi segi. Segi yang menjadi kajian dalam tulisan ini berupa penilaian portofolio berbasis gaya belajar siswa. Gaya belajar siwa yang dimaksud yaitu gaya belajar visual, auditori dan kinestetik. Gaya belajar dijadikan atribut tambahan dalam penyusunan instrumen penilaian portofolio dengan tujuan agar siswa selama mengerjakan tugas-tugas portofolio akan cepat dan mudah terasah dalam mengembangkan kompetensinya secara menyeluruh, baik kompetensi kogniti, afektif maupun psikomotor.

\section{UCAPAN TERIMA KASIH}

Tulisan ini terwujud atas dukungan beberapa pihak, di antaranya Ketua STKIP Siliwangi Bandung beserta jajarannya yang selalu memberi dukungan kepada penulis baik moril maupun materi untuk melakukan penelitian dan mengikuti seminar atau pertemuan ilmiah di berbagai tempat. Selain itu, keluarga tercinta, suami dan anak-anak yang selalu memberi cinta kasih dan perhatian yang berlimpah.

\section{PUSTAKA RUJUKAN}

Ahiri, J dan Hafid, A. 2011. Evaluasi Pembelajaran dalam Konteks KTSP. Bandung: Humaniora.

Arifin, Z. 2011. Evaluasi Pembelajaran. Bandung: Rosdakarya.

Anderson, L dan Krathwohl, D. 2010. Kerangka Landasan untuk Pembelajaran, Pengajaran, dan Asesmen. Terjemah Agung Prihantoro. Yogyakarta: Pustaka Pelajar.

Brown, D. 2008. Prinsip Pembelajaran dan Pengajaran Bahasa, Edisi Kelima. Terjemahan. Amerika Serikat: Pearson Education.

Departemen Pendidikan Nasional. 2004. Pedoman Pengembangan Portofolio untuk Penilaian. Jakarta.

Illeris, K. 2011. Teori-teori Pembelajaran Kontemporer. Terjemah M. Khozim. Bandung: Nusa Media.

Kementrian Pendidikan dan Kebudayaan. 2013. Pengembangan Kurikulm 2013. Paparan Mendikbud.

Kementerian Pendidikan dan Kebudayaan. 2013. Buku Guru Bahasa Indonesia SMA. Jakarta: Politeknik Negeri Media Kreatif.

Peraturan Presiden Republik Indonesia No. 8 Tahun 2012 tentang Kerangka Kualifikasi Nasional Indonesia

Rahyubi, H. 2012. Teori-teori Belajar dan Aplikasi Pembelajaran Motorik. Majalengka: Referens

Soewandi, S. 2006. Penilaian Pembelajaran dengan Porftofolio. E-journal. Universitas Sanata Darma.

Thobroni, M dan Mustofa, A. 2011. Belajar dan Pembelajaran. Yogyakarta: ArRuzz Media.

Wikanengsih. 2012. Model Pembelajaran NLP Berorientasi Karakter dalam Pembelajaran Menulis Persuasi Siswa SMP. Disertasi. Bandung: UPI.

Yamin, M. 2011. Paradigma Baru Pembelajaran. Jakarta: Gaung Persada Press. 
bahasa \& sastra, Vol. 14, No.1, April 2014 